\title{
AZ ORVOSI BIOMECHANIKA TÖRTÉNETE
}

\section{Csernátony Zoltán}

Debreceni Egyetem, Orvos- és Egészségtudományi Centrum, Ortopédiai Klinika csz@med.unideb.hu

Akár tanítás, akár díszítés céljából készültek is, a barlangrajzok valahol a normál mozgások, mozgássorozatok iránti érdeklődés mutatói. A mozgások tanulmányozása ezek szerint egész az ősidőkre tekint vissza.

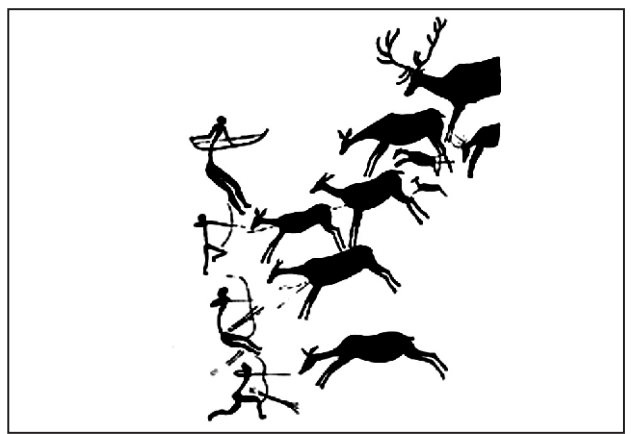

Barlangrajz az Altamira-barlangból

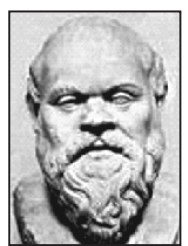

Szókratész

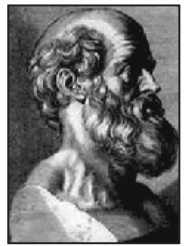

Hippokratész
A tudományok történetének vizsgálatakor rendszerint az ókori görögökig jutunk vissza. Igy van ez a biomechanika esetében is. Mint Szókratész (Kr. e. 470-399) tanította már 2400 évvel ezelőtt, nem érthetjük meg a környező világot, amíg nem ismerjük meg saját természetünket.

Már az orvoslás atyja, Hippokratész (Kr. e. 460-377) behatóan foglalkozott többek között a csonttörések és ficamok kezelésével is, és számos elmés mechanikus repozíciós, korrekciós és rögzítô szerkezetet alkalmazott, amelyek mögött feltétlenül komoly biomechanikai ismereteknek kellett állniuk.

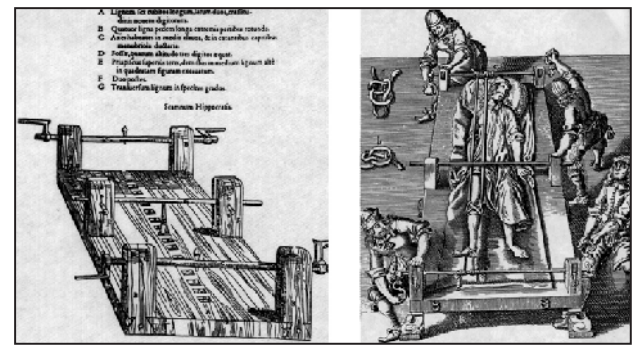

Hippokratész scammonja.

Bizonyos elemeiben napjainkban is korszerú szemléletet mutat a törések repozíciójában

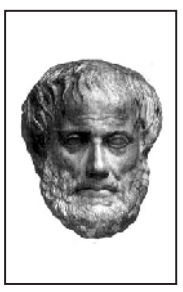

Arisztotelész

Magának a kineziológiának, a mozgások tudományának (kinein $[\mathrm{gr}]=$ mozogni, logos [gr] = tudomány, értekezés) az eredete is visszakövethetô az ókorig. Általánosan elfogadott nézet szerint a kineziológia atyja Arisztotelész (Kr. e. 384-322). Ezt megalapozó mûveiben ( $A z$ állatok részei, $A z$ állatok mozgásai, Az állatok elôrehaladása) leírta az izmok múködését, és elsőként végezte el geometriai analízisüket. Ugyancsak elsőként analizálta az emberi mozgást, amit mint „a rotációs mozgások transzlációs átalakulását” határozott meg.

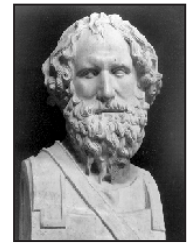

Arkhimédész
Arkhimédész (Kr. e. 287-212) a vízben lebegố testekkel kapcsolatos hidrosztatikai nyomást határozta meg, de már foglalkoztatták a súlypontmeghatározás és a felhajtóerô kérdései is. Ôt tartják az elméleti mechanika megalapítójának. 


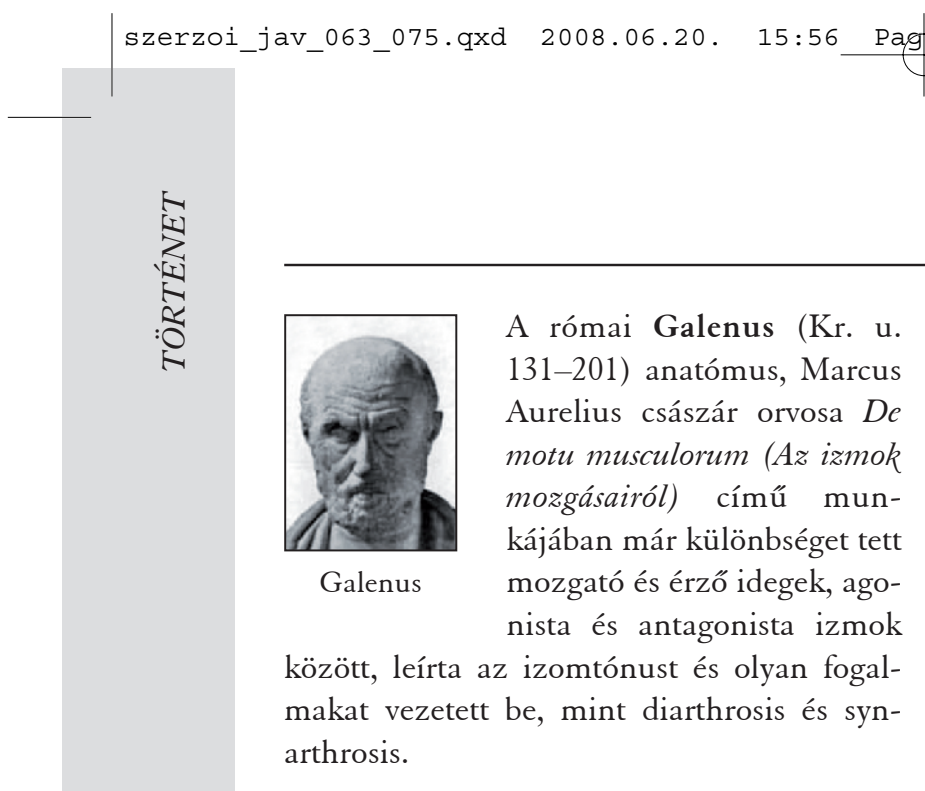

Tanításai szerint az izomkontrakciókat az váltja ki, hogy állati lelkek vándorolnak az agyból az idegeken keresztül az izmokba. A pergamoni gladiátorok orvosi felügyeletét is ô látta el, így az első sportorvosként, fenti múvét az elsố sportorvosi könyvként, és mindezekből következően személyét a sportorvoslás atyjaként is tekintik. De gyakorló orvosként is maradandót alkotott. Nevéhez füződik a scoliosis (gerincferdülés) elnevezése, ami a scolios $\sigma \chi 0 \lambda \iota 0 \sigma$ (=kanyargós) görög szóra vezethetô vissza. A scoliosis esetében ekkor még a jelentôs bordapúp eltüntetésének az óhaja vezette mind a beteget, mind a kezelőorvost. Galenus scoliosis kezelési módszere jól tükrözi ezt a mechanisztikus megközelítési módot.

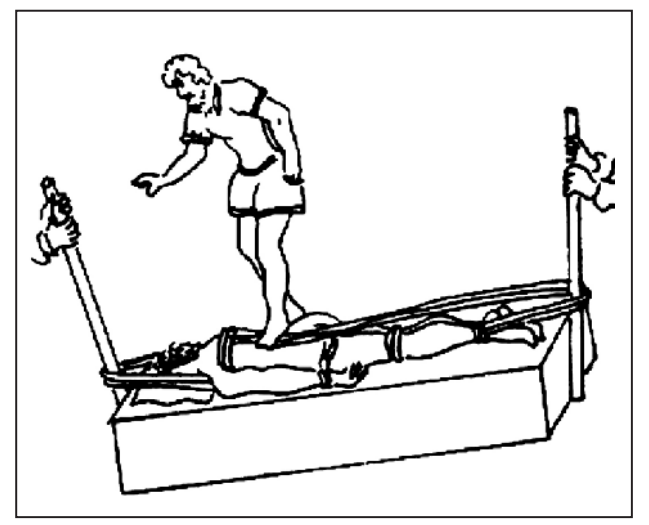

Galenus scoliosis korrekciós technikájában - ugyanúgy, mint napjainkban is már jelen vannak az elongáció és derotáció motívumai

Galenus tanításainak hallatlan nagy hatását mutatja, hogy ezt követôen hosszú évszázadokig nem született hasonló mú sem az anatómia, sem a biomechanika területén.

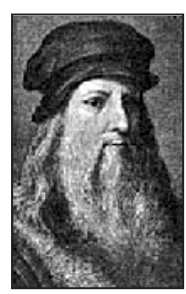

da Vinci
A kineziológia és az anatómia egész a XV. századig gyakorlatilag változatlanul a helyenként misztikus galenusi tanulmányok alapján nyugodott, amikor is Leonardo da Vinci (1452-1519), a mûvész-mérnök-tudós, az emberi és állati test felépítését titokban végzett boncolásai során vizsgálta.

Munkája során a csontokat és az izmokat betûjelzésekkel látta el, és ezekrôl mûvészi értékû, ugyanakkor tudományos igényú ábrákat készített. Egy idő után azonban már nem elégítették ki a boncolással nyerhetô ismeretek, és a mozgásszervek múködésének kérdései felé fordult. Foglalkoztatták a súlypont és az egyensúly kérdései is. Vizsgálta a test mechanikáját állás, ülésbôl felállás, vízszintes talajon történô járás, illetve hegyre fel- és hegyről lemenet és ugrás közben. A különböző izmok hatásának és együttmúködésének eredményeit a csontvázra az izomeredésnek és -tapadásnak megfelelốen felerôsített kötelekkel demonstrálta. Különösen a gerinc múködése érdekelte. Ố adta a gerinc első helytálló leírását mind a struktúráját, mind a statikáját illetốn. Befejezetlen múvében, De Figura Humana (Emberi ábrák) programként hirdeti meg mechanikai szemléletét. Mint írja: „A mechanika tudománya a legnemesebb és mindenek felett a leghasznosabb, látnivalóan minden élö test általa végzi mozgásait.” da Vinci munkásságának sok részlete sokáig nem került nyilvánosságra, így értékének megfelelő hatást sem gyakorolhatott kora tudományára. 


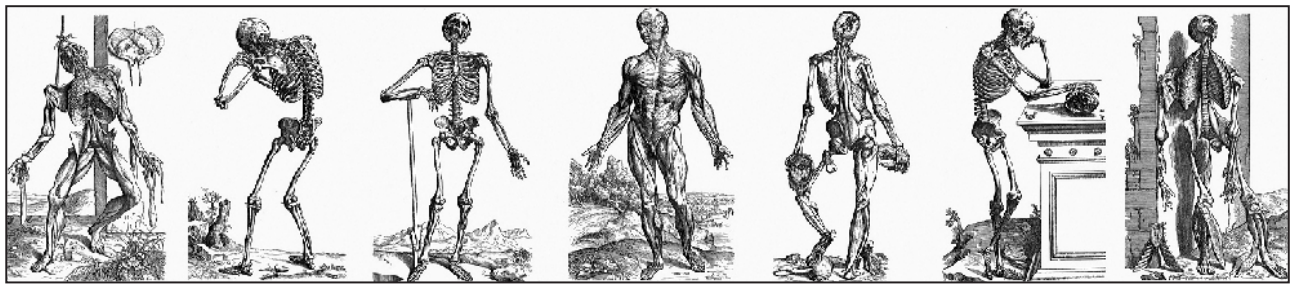

Ábrák Vesalius múvéből



Vesalius
Andreas Vesalius (15141564) is munkásságának egy komoly fejezetét szentelte az emberi szervezet funkcionális szemléletû anatómiai megismerésének. Fő mûvében De Humani Corporis Fabrica (Az emberi test felépitéséról) több, a Galenus munkáiban talált hibát javított ki.

Ugyanakkor elhíresült hibás medenceábrázolása épp a biomechanikai szemlélet hiányának kedvelt példája.

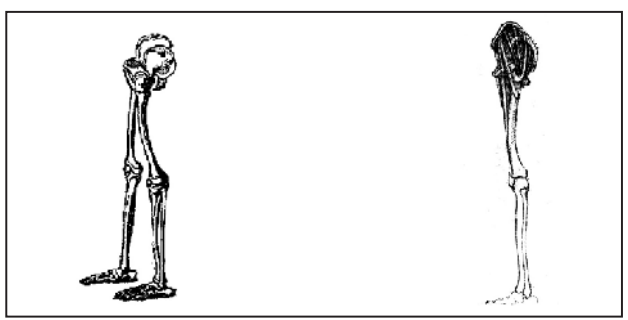

Vesalius elhíresült helytelen és da Vinci helyes medencestatika ábrázolása

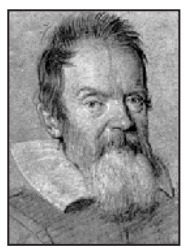

Galilei
Galileo Galilei (1564-1642) orvostanhallgatóként kezdte pályafutását. Munkássága révén elôször vált lehetővé fizikai események matematikai leírása, ami többek között a kineziológia tudományos továbbfejlődésének is az egyik záloga volt. Az emberek pulzusszámát például az ingamozgások szabályosságára alapozva az inga hosszának mértékében határozta meg. 1638-ban írt Két új tudomány címú könyvének alcímében használta elôször a mechanika szót az erô, a mozgás és az ellenállás leírására. A biomechanikára kifejtett hatása személyes eredményein túl tanítványai munkásságán keresztül is érződött.

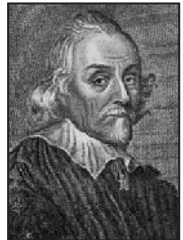

Harvey
William Harvey (1578-1657), aki Páduában volt hallgatója Galilei híres előadásainak, 1615-ben alkotta meg a vérkeringésrôl alkotott tézisét, amit aztán 1628-ban demonstrált híres kísérletében.

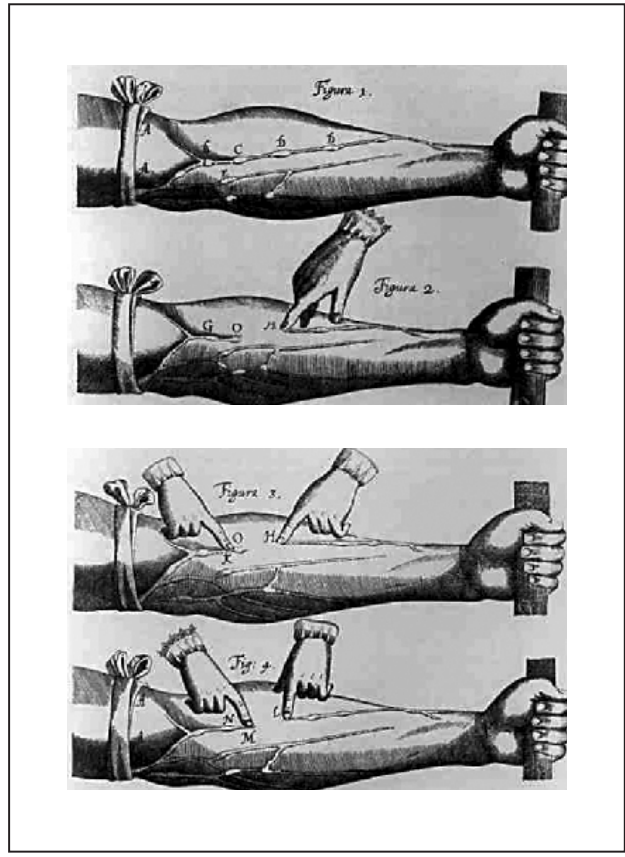

Harvey ábrái a vérkeringés tényének bizonyítására 


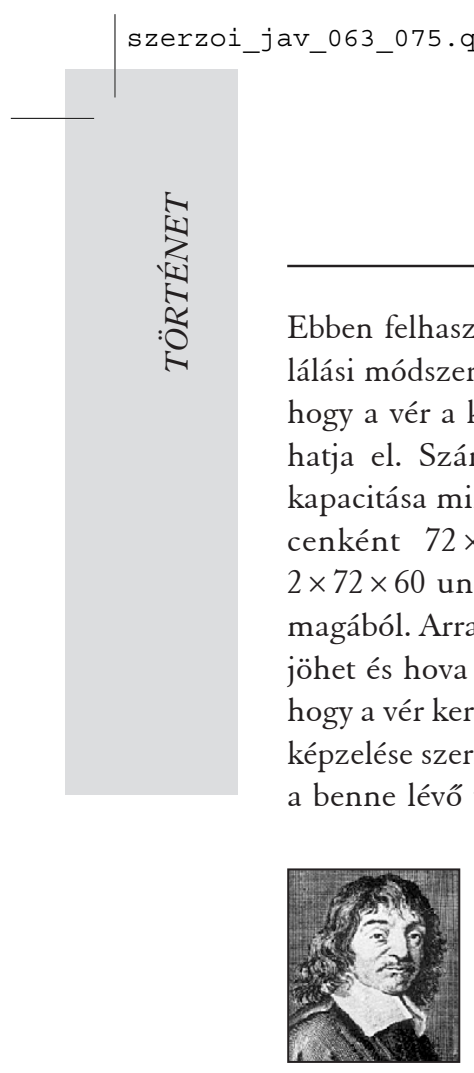

Descartes

Ebben felhasználta Galilei ingás pulzusszámlálási módszerét is. Ố bizonyította be elsőként, hogy a vér a kamrát csak egy irányban hagyhatja el. Számításai szerint a szív térfogatkapacitása mintegy 2 uncia, így ha a szív percenként $72 \times$ ürít vért, akkor óránként $2 \times 72 \times 60$ uncia $=234 \mathrm{~kg}$ tömegû vért lök ki magából. Arra keresve a választ, hogy honnan és hova mehet ilyen tömegû vér, rájött, hogy a vér kering, és ennek motorja a szív. Elképzelése szerint a szív szerepe átadni a vérnek lévố természetes meleget és életerốt. 1675-ben megjelent Tractus Homine et de Formatione Foetus (Az emberi szervezet és a foetus képzódéséról) címú munkájában a testet egy Isten keze által készített gépnek tekintette, és állította, hogy éppen ezért a mechanika módszerei alkalmasak a tanulmányozására.

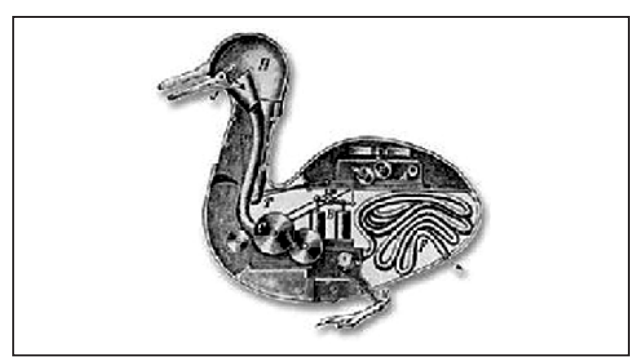

Descartes szellemében, de nem általa készített ábra az élő szervezetről

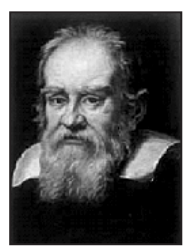

Borelli
Giovanni Alfonso Borelli (1608-1679) olasz orvos-matematikus-csillagász, Galilei barátja volt. 1673-ban megjelent könyve, De Motu Animalium (Az állatok mozgásáról) az elsô szisztematikus kísérlet az állatok és az ember mozgásának mechanika szemléletû analízisére.

Így mondhatjuk, hogy ez tekinthetô az első ismert biomechanikai indíttatású múnek. Az izommúködés és a test dinamikájának tisztázásában úttörố szerepe volt. Így természetesen az ő munkájában is megjelent az emberi test súlypontjának meghatározása.

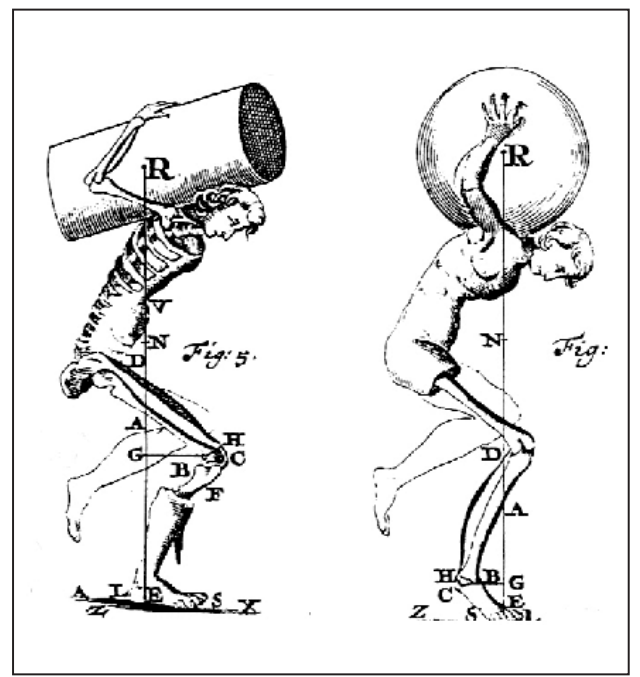

Borelli már a munkavégző ember mechanikai elemzésére is vállalkozott

A súlypontmeghatározáshoz méréseket végzett: meztelen férfiakat kötözött egy deszkához, amit aztán egy késélen addig helyezgetett, míg megtalálta az egyensúlyi helyzetet. Foglalkozott a szív és a belek mozgásaival is. Úttörố szerepe mellett rendkívül haladó szemléletét is meg kell említeni: a funkció megértésében támaszkodik az állatvilág biomechanikai elemzésére, és az embert mint munkavégzô lényt is elemzésnek veti alá. Ezzel mintegy a munkaegészségtan alapjait is lerakta.

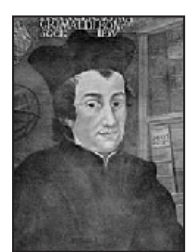

Grimaldi
$\mathrm{Az}$ olasz jezsuita Francesco Maria Grimaldi (1618-1661) elsőként számolt be az izomkontrakció során észlelhető hangjelenségekről. Ilyen vizsgálatokat aztán legközelebb 300 évvel késôbb végeztek! 
William Croone (1633-1684) az agy és a kontraháló izmok közötti jeladást vizsgálta. De Ratione Motus Musculorum (Az izmok müködéséról) írása az egyik korai komoly munka az izommúködéssel kapcsolatban. Ennek kapcsán már évente rendeztek Angliában izomélettani előadásokat.

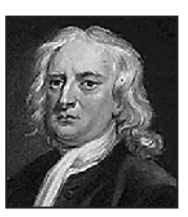

Newton
Isaac Newton (1642-1727) Principa mathematica philosophiae naturalis (A természet filozófiájának matematikai princípiuma) címú múvében lerakta a modern dinamika alapjait. Három törvénye, amelyekben az erôhatásokat és azok kölcsönösségét írja le, természetesen a kineziológia további fejlődését is alapvetôen meghatározta.

I. Minden test megtartja nyugalmi állapotát vagy egyenes vonalú egyenletes mozgását, míg egy másik erố ennek megváltoztatására nem kényszeríti.

II. A mozgás változása arányos a beható erôvel, és iránya a behatás irányával megegyezô.

III. Két test egymásra hatásakor mindig azonos nagyságú, de ellentétes irányú erốk lépnek fel.

A három törvényt jól demonstrálja a diszkoszvetô példája: amíg forog a koronggal, erôsen kell fognia, hogy el ne szabaduljon a kezéból, így olyan erôvel fogja, amilyen erôt az a kezére gyakorol (III. törvény). Elengedés után megszûnik a centripetális erô, és a diszkosz egyenes vonalú mozgással folytatja útját az azt elindító erő arányában (II. törvény). A megtett távolságot befolyásolja a gravitáció, a sebesség és minden további olyan tényező, ami az egyenes vonalú egyenletes mozgást módosítja (I. törvény).

Ezen túlmenốen Newton alkotta meg az erôvektorok parallelogramma szabály szerinti összegzésének módszerét is. A biomechanikában a vektorok összegzésének nagy jelen- tôsége van, mint pl. az izmok hatásmechanizmusának számításakor, figyelembe véve, hogy vannak azonos helyen eredő, de különbözô helyeken tapadó és különböző helyeken eredő, de azonos helyen tapadó izmok is.

Bár késôbb az einsteini világnézet bizonyosságát adta, hogy a newtoni világnézet szigorúan csak abban a kapcsolatrendszerben alkalmazható, amelyikben keletkezett, de a kineziológia számára ettôl függetlenül mind a mai napig tökéletes rendszert képez.

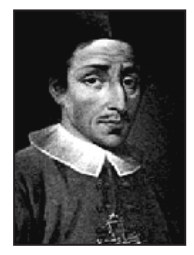

Stensen
Niels Stensen (1648-1686) szenzációs felfedezése volt, hogy a szív tulajdonképpen egy izom, és nem a természetes melegség és az életerô központja. Korszakalkotó múvével, Elementorum Myologiae Specium (A fajok izomtanának alapjai) lefektette az izommechanika alapjait.

Ebben az izmokat kis motoros rostok együtteseként tekinti, az izomfelépítésben pedig felismeri, hogy az izmoknak csak a középső része húzódik össze, a két tapadásra szolgáló végük nem. Megállapítja, hogy a rövidülés az izomrostok kontrakciójából adódik, és az izomállomány mennyiségi változásával nem jár.

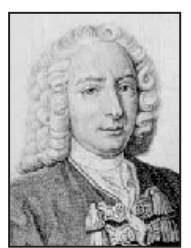

Bernoulli
Johann Bernoulli (16671748) korának kiemelkedő tudósa mind orvosi, mind matematikai tanulmányokat folytatott. Orvosi értekezését a fermentációról írta, de foglalkoztatták a deriválás és az integrálás kérdései is. A folyadékok áramlási sebessége és nyomása közötti összefüggés törvényét is ő alkotta meg. Próbálkozott az emberi munkavégzés optimális mennyiségének meghatározásával is a kifejtett erô, a sebesség és az idő függvényében.
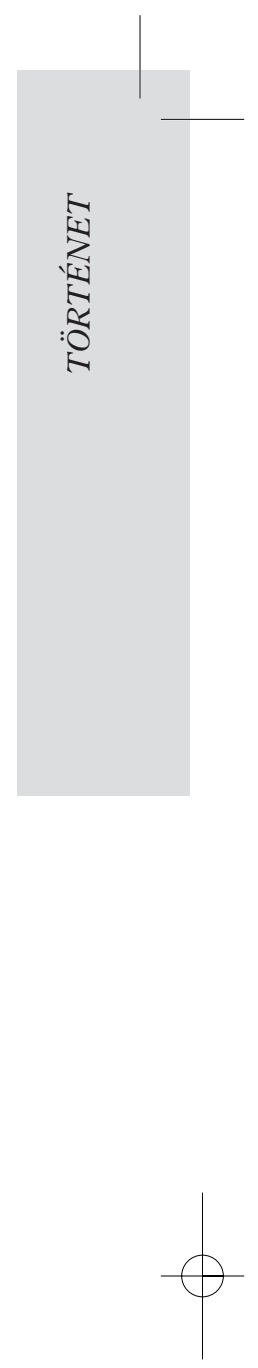


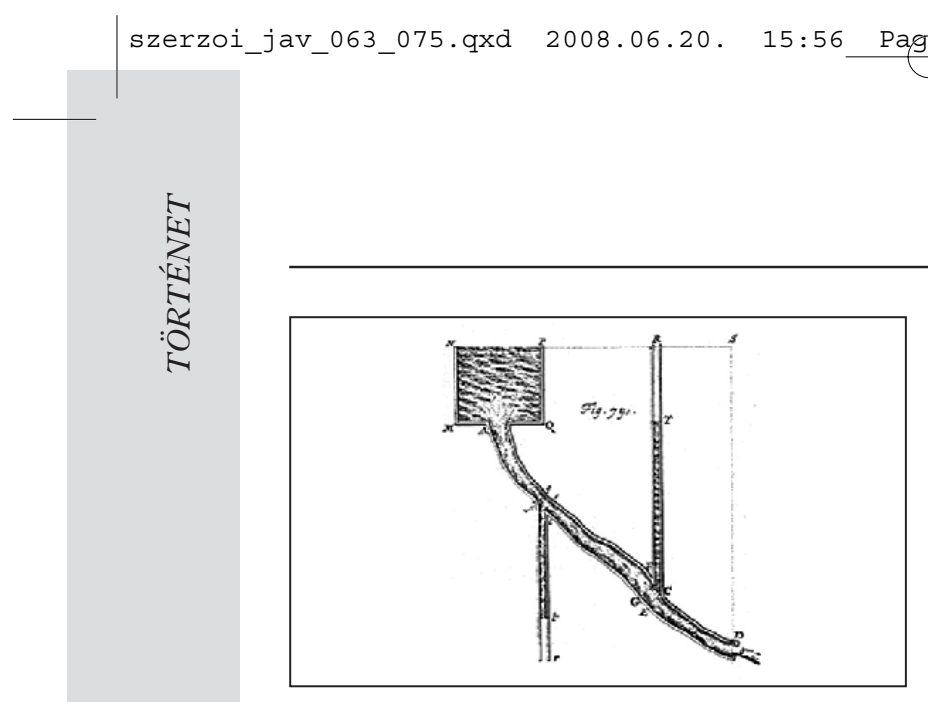

A Bernoulli-törvény demonstrációjának eredeti ábrázolása

James Keill (1674-1719) An account of animal secretion, the amount of blood in the human body, and muscular motion címú múvében megszámolta, hogy melyik izomban hány izomrost található, és megállapította, hogy izomkontrakció során mindegyik rost kerek keresztmetszetû lesz és rövidül. Hibásan azonban arra a következtetésre jutott, hogy egyik izom sem rövidülhet hosszának harmadánál kevesebbre.

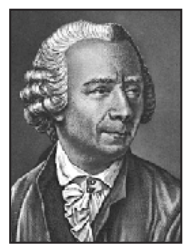

Euler
A svájci matematikus, fizikus és csillagász, Leonhard Euler (1707-1783) az oszlopok mechanikai modellezésén keresztül a gerinc stabilitásával kapcsolatban tett máig is érvényes megállapításokat. Bevezette a kritikus terhelés fogalmát, ami után az oszlop (gerinc) összeomlik.

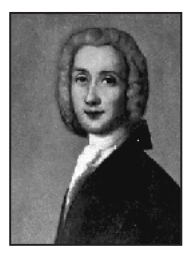

1740 körül az élettanászokat lázba hozta a felismerés, hogy elektromossággal az izmokat ingerelni lehet. Robert Whytt (1714-1766) betegek elektromos kezelésével szerzett klinikai tapasztalatokról számolt be. Az „életerő” és az „állati lélek” helyett már „állati elektromosságról” kezdtek beszélni és ebben látták az izommúködés kiváltó tényezőjét.

Biomechanica Hungarica I. évfolyam, 1. szám

John Hunter (1728-1793) gyújtötte össze és szintetizálta az anatómusok és élettanászok izommúködéssel kapcsolatos addigi eredményeit. Munkáját, mint a XVIII. század tudományos izomélettani összefoglalóját tekinthetjük. Részletesen foglalkozott az izmok alakjával, felépítésével és ingerelhetőségével is.

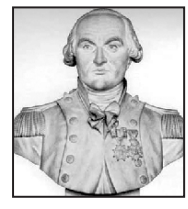

Coulomb

Charles Augustin de Coulomb (1736-1806) azon túl, hogy a fizika számos területén nagyot alkotott, szintén foglalkozott az emberi test mechanikai és energetikai kérdéseivel. Ugyancsak az ő egyszerú és elegáns kísérletének köszönhetôen vált elôször lehetôvé minimális erôk mérése terhelés mellett felfüggesztett selyemés hajszálak torziójából származó erôk segítségével.

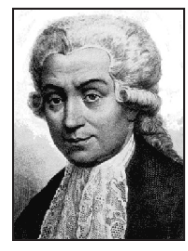

Galvani
Luigi Galvani (1737-1798) békacombokon próbálta vizsgálni a légköri elektromosság hatását. A drótra felfűzött combokhoz szikével hozzáérve azok kontrakcióját tapasztalta. 1791-ben publikált mûve De Viribus Electricitatis

in motu musculari commentarius (Kommentár az elektromosság izommozgásra gyakorolt hatásáról) az elsô világos állítás az izommozgás és az idegingerület elektromos természetét illetốen. Munkássága révén Galvanit tekintjük az experimentális neurológia atyjának.



Galvani híres békakísérletei 


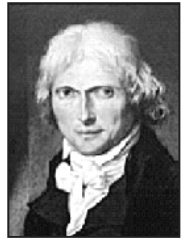

Bichat

$\mathrm{Az}$ anatómia oktatása egészen

Marie Francois Xavier Bichat

(1771-1802) koráig a régi korokban lefektetett dogmák alapján történt. Bichat kísérleti munkássága révén indult meg a modern anatómia fejlôdése. Ő ismerte fel, hogy a különböző szervek különböző szövetekból épülnek fel. A synovialis membránt is ő írta le elsôként. Ôt tekintjük a funkcionális anatómia, a leíró élettan és pathológia megalapítójának.



Duchenne

Elragadtatva az elektromos stimulációban rejlő lehetôségektól, Guillaume Benjamin Amand Duchenne (18061875) kísérletekbe kezdett az egyes izmoknak a mozgások létrehozásában játszott szerepének tisztázására. Felismerte, hogy izolált izomkontrakció a természetben nem fordul elö. Eredményeit a Physiologie des mouvements (A mozgások élettana) címú múvében összegezte.

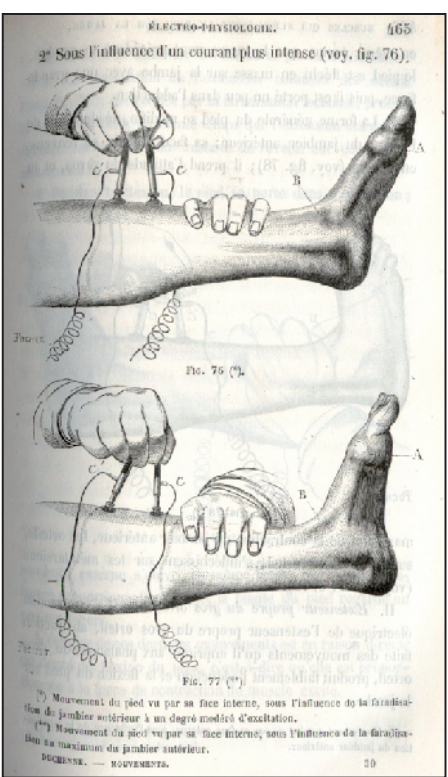

Ábra Duchenne könyvéból

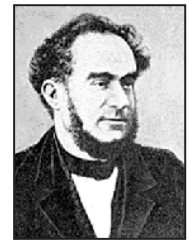

Matteucci

Carlo Mateucci (1811-1868) az elektrosztatika, az elektrodinamika és az elektrofiziológia területén ért el figyelemre méltó ereményeket. Galvani munkásságát folytatva sikerült bizonyítania, hogy a sérült szövetek elektromosságot termelnek, és ilyen sérült sebeket elektromosan sorba kötve nagyobb feszültséget kapunk. Feltételezte, hogy az állati szervezetekben van egy „disequilibirumot létrehozó szerv". Ezt az elektromosságot nem tartotta összefüggő́nek a központi idegrendszerrel. Béka preparátumot használt, amit „békareoszkóp”-nak nevezett, amiben a béka átvágott idege elektromos szenzorként szolgált, és az izom rángása volt a vizuális bizonyíték az elektromosságra. A békának - Galvani nagy felfedezettjének - a sorsa ezzel végleg megpecsételődött és évszázadokra a tudomány nagy mártírjává vált.

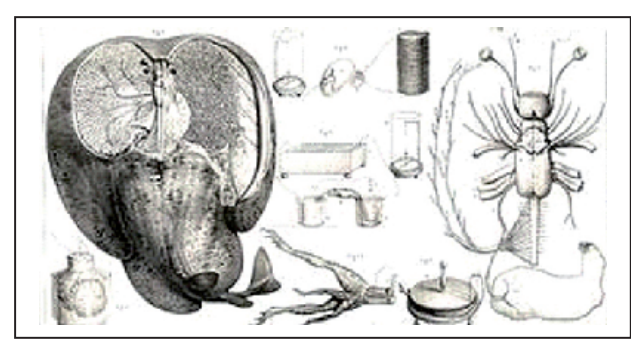

Mateucci béka-reoszkópja

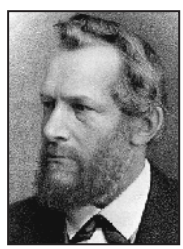

DuBoisReymond

Az állati elektromosság egyszerre az egyik leginkább kutatott témává vált. A kérdés legnagyobb kutatója Emil DuBois-Reymond (18181896) volt, aki munkásságával lefektette a modern elektrofiziológiát. 1848-ban demonstrálta az idegek akciós potenciálját, és 1849-ben EMG-vizsgálatot végzett. Foglalkozott az agy-lélek kapcsolattal is. 


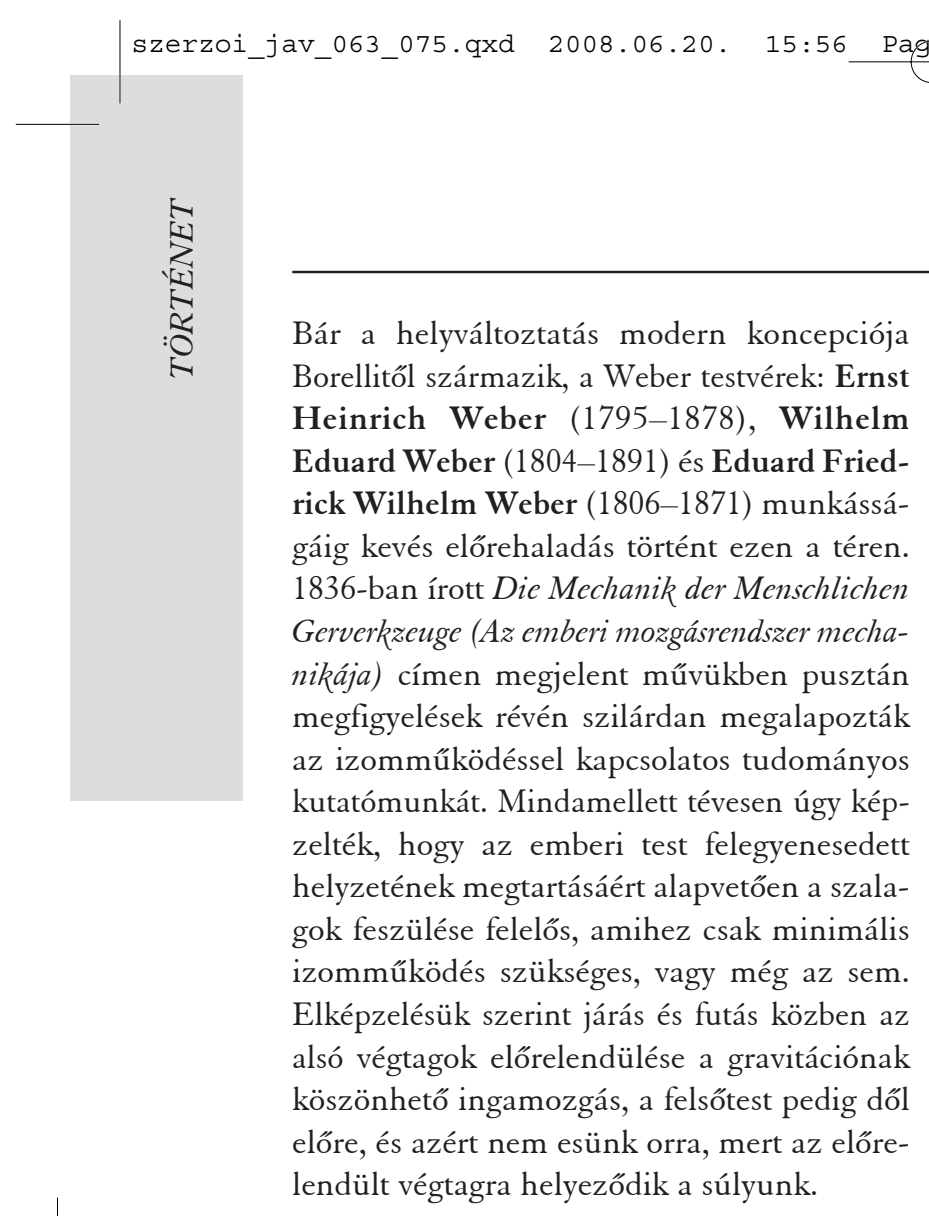

Ugyanakkor számos helytálló megállapítást tettek a testtömegközéppont helyzetének járás közbeni változásáról, illetve a hosszú csöves csontok, mint erôkarok szerepérôl a végtagok mozgásai során. Elsők között foglalkoztak a járás, futás, ugrás analízisével.

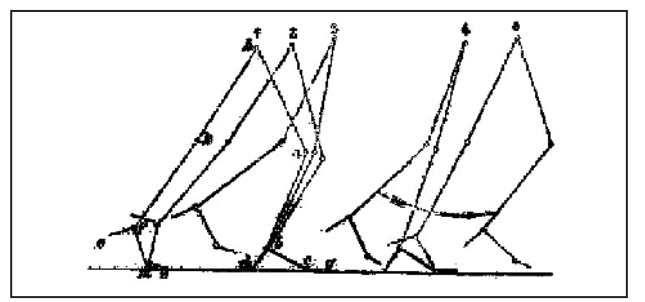

A Weber testvérek járásanalízise a lépés fő fázisainak pontos értelmezését adja

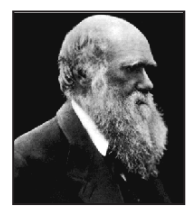

Darwin
Charles Darwin (1809-1882) 1859-ben publikálta The origin of the species címú munkáját, ami forradalmian átalakította az emberi testról alkotott véleményeket. Az embert „egy korábbi létezô forma módosult leszármazottjaként" tekintve elmélete alapján a kineziológia számos kérdésére sikerült magától értetôdô választ találni.

Szemben a korábbi spekulatív és indirekt eljárásokkal, E. Harless direkt módon próbálta az egyes testszegmentumok paramétereit meghatározni, és munkáját kiterjesztette a testtömegközéppont axiális tengely mentén történő elmozdulásának meghatározására is. Eredményeiról a Bajor Királyi Akadémián számolt be 1860-ban. Kísérleteit két kivégzett bűnöző 18 darabra vágott tetemén végezte. A nagyízületeket a forgástengelyen átfektethetô síkokban vágta fel. A test átlagos sưrúségét $1,066 \mathrm{~g} / \mathrm{cm}^{3}$-ben határozta meg. Késóbbi kísérleteiben bizonyította, hogy ez nagy ingadozásokat mutathat az életkor és a nem függvényében.

Ebbốl a korból számos egyéb példa is van arra vonatkozólag, hogy egyes kutatók az igazságszolgáltatás oldalvizein is igyekeztek minél több tudományos ismeretet szerezni. A. M. Paterson 1890-ben elsóként írta le a nyaki csigolyák sérülési mechanizmusát áll alatti csomóval végzett akasztás esetén. Az általa vizsgált személyeknél a C2 pediculusai törtek, a ligamentum longitudinale anterius és posterius elszakadt, és a hátsó ív caudal felé mozdult.

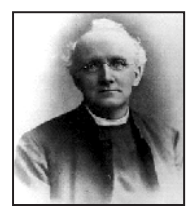

Haughton
A gerinces állatok mozgásával foglalkozó tudósok közül kiemelkedett Samuel Haughton (1821-1897), aki számos munkájával (Outlines of a new theory of muscular function, Notes of animal mechanics stb.) nagyban hozzájárult a biomechanikai és kineziológiai ismeretek gyarapodásához. A vizsgálati módszerek azonban ebben a korban még hiányosak voltak: nem volt lehetôség a mozgások kronológiai elemzésére. 


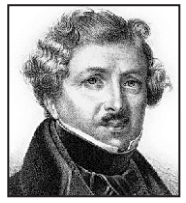

Daguerre

Az 1837-ben Louis Jacques Mandé Daguerre (17871851) által kidolgozott fotográfia lehetôvé tette a mozgások pontos képi rögzítését. A fejlődésnek indult fényképezési eljárások aztán új utakat nyitottak meg a kísérletek számára.

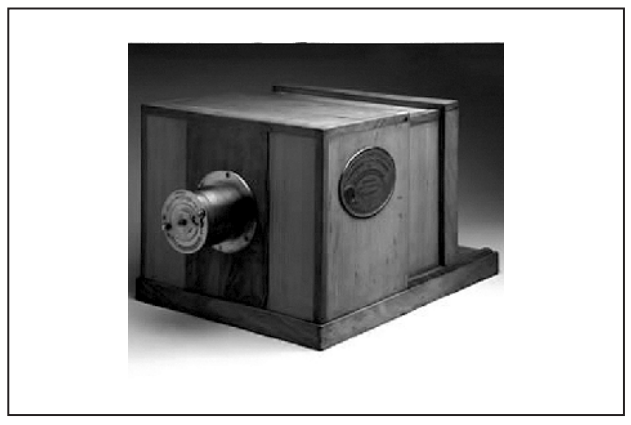

Daguerre fényképező készüléke

Ezt követôen a legkülönbözőbb fényképező alkalmatosságok születtek, majd megjelent a sorozatfelvételek és ennek folyományaként a mozgókép-felvételezés technikája.

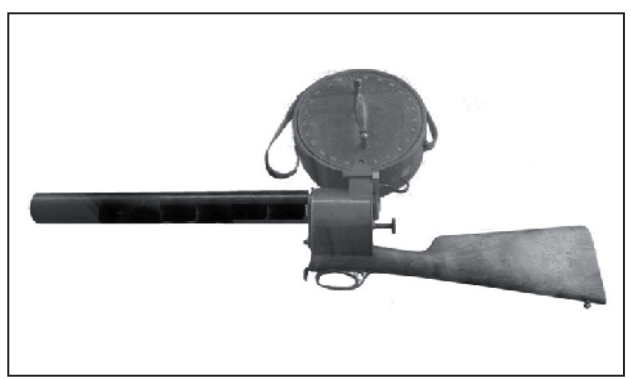

Puska fotográf a XIX. század végéről

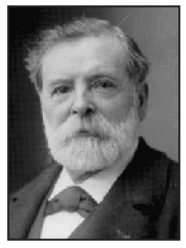

Marey 1872-ben Étienne-Jules Marey (1830-1904) járó, futó és ugró emberek mozgás közben készített fotóiból állított össze mozgássorozatot, és a járást biomechanikai szempontból elemezte.

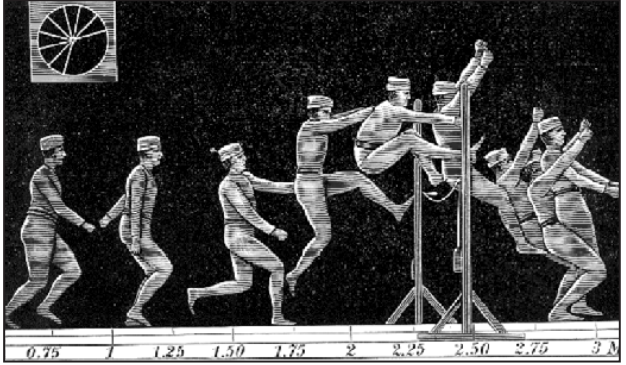

Marey sportmozgáselemzése

A járáselemzés mozgáselemzés részén túlmenôen foglalkozott a talp-talaj kontaktusban fellépő erők mérésével is, amihez erőmérôvel ellátott cipőtalpat készített. Késôbb, 1882-ben kidolgozta a sorozatfényképezés egyik technikáját, amit kronofotográfiának neveztek el. Ennek lényege az volt, hogy 12 külön felvételt lehetett készíteni ugyanarra a lemezre. 1888ban pedig elkészítette az első flexibilis filmet.

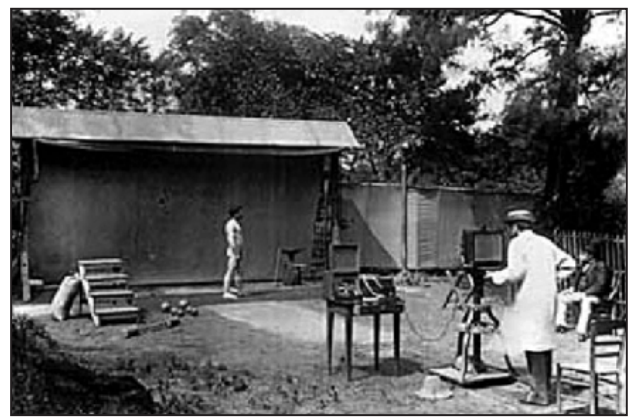

Marey kronofotográfiás felvétel készítése közben

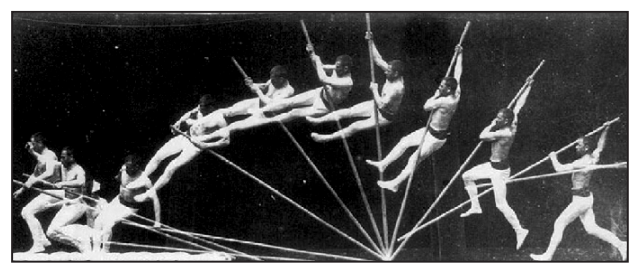

Rúdugrás kronofotográfiás ábrázolása

A mozgások kronológiai dokumetálásához egyébként az ötletet a Vénusz 1878-as áthaladásáról készült sorozatképek adták. Edward Muybridge (1831-1904) The horse in motion
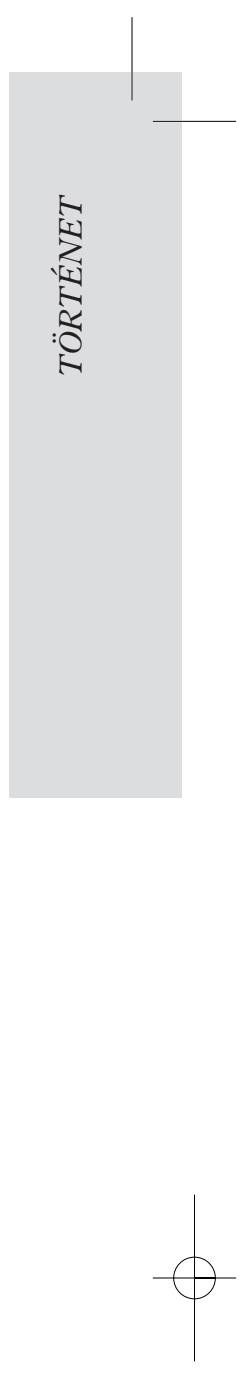

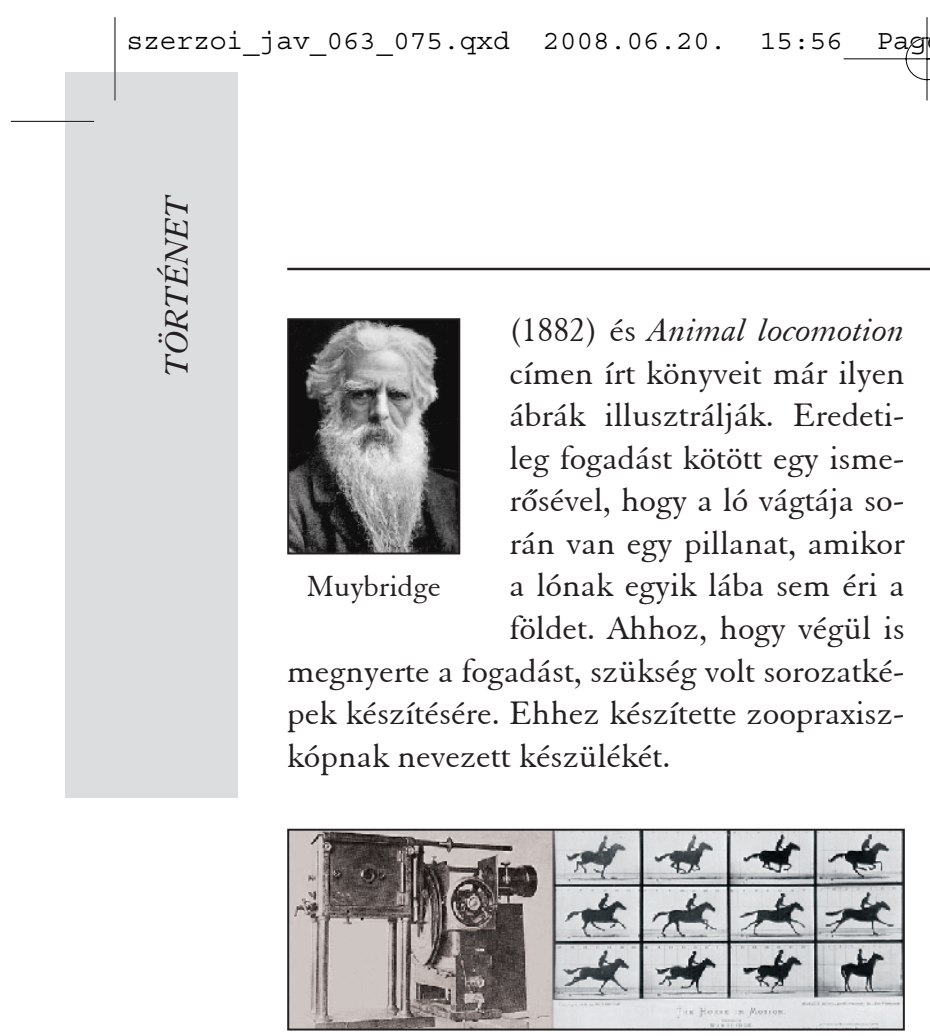

Muybridge zoopraxiszkópja és az ezzel készült híres képsorozat

Carlet (1845-1892) továbbfejlesztette Marey erőmérővel ellátott cipőtalpát, és külön erômérést végzett az előlábon és a lábtő́ben. A mérés alanya egy 20 méter átmérôjű körön járt, és az erôméréssel egyidejűleg a medence vertikális és oldalirányú oszcillációját is mérte.

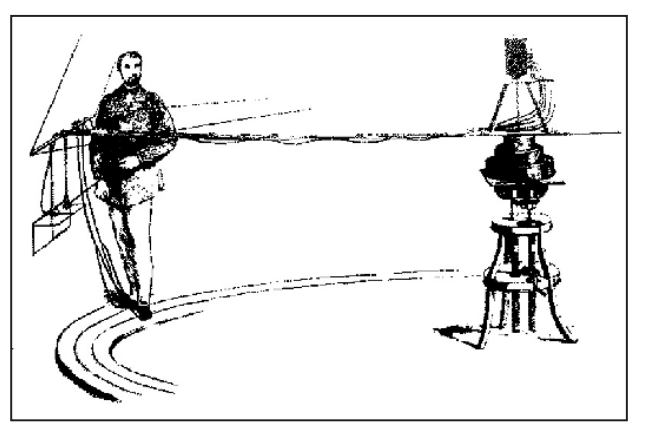

Carlet erőmérő rendszere

Herrmann von Helmholtz (1821-1894) a fiziológia és a pathológia professzora Königsbergben, Bonnban majd Heidelbergben az optika, a termodinamika és az akusztika területén végzett kiemelkedő munkát. A szem fókuszáló képességének és a színlátás trikro-

Biomechanica Hungarica I. évfolyam, 1. szám

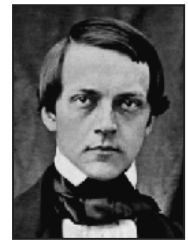

von

Helmholtz

matikus elvének kidolgozása fűzôdik a nevéhez. Elsôként határozta meg az idegvezetés sebességét, amit $30 \mathrm{~m} / \mathrm{s}-\mathrm{nak}$ mért, és ô bizonyította be az izommunka által termelt hô szerepét az állatok testhőmérsékletének kialakításában.

1888-ban Thomas Alva Edison (1847-1931) és Edward Muybridge 90 állókép összeragasztásával elkészítette az elsô mozgófilmszerú bemutatót. Tervük az volt, hogy a késóbbiekben ezt Edison fonográfjával hangosítsák.

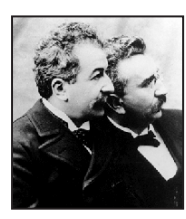

Lumière testvérek

Louis (1864-1948) és August Lumière (1862-1954) 1895ben mutatták be a mozgófilmvetítés technikáját, ami új lehetôségeket nyitott a biomechanikai mozgáselemzés számára is.

Christian Wilhelm Braune (1831-1892) és Otto Fischer (1861-1917) német tudósok az emberi járómozgást elemezték, és az emberi testben lévô csuklókapcsolatok kinematikáját vizsgálták. Mind a mai napig az ő munkásságuk révén fejlődött legtöbbet a járásanalízis. Felismerték, hogy a testtömegközéppont pontos ismerete szükséges az izmokra háruló munka megértéséhez. Ehhez 1889-ben dolgoztak ki új módszert. Fagyasztott tetemeket rögzítettek hosszú acélszegekkel egy falhoz. Ezután meghatározták a három fố síkot, amelyekben megtalálható a testtömegközéppont is. Ezt követôen a holttestek darabolásával eljutottak a keresett pontig.

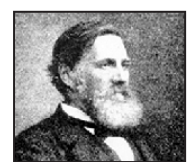

Braune
Braune ezen túlmenôen új szemléletû térhatású anatómiai ábráival is beírta magát az orvostörténelembe.

\section{2}




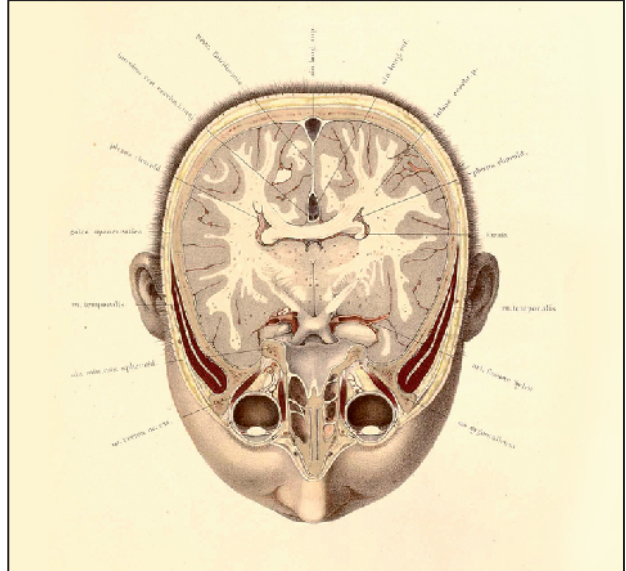

Koponyaábrázolás Braune anatómia atlaszában

Wilfrid Taylor Dempster (1905-1965) késốbb megismételte Harless cadaver darabolásos kísérleteit. 8 idôs ember tetemét vizsgálva térfogat-, sûrûség-, tömeg-, tömegközéppont- és inertiamérést végzett, majd a testeket részekre bontotta, és a méréseket azokon is elvégezte.



Fick

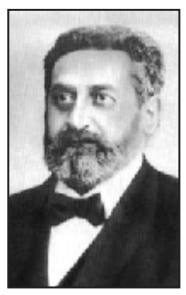

Wolff
Adolf Eugen Fick (18291901) számos új megállapítást tett az izomélettan és energetika területén. Bevezette az izometriás és az izotóniás gyakorlatok fogalmát. Munkásságának egyébként szemészeti vonatkozása is van, nevéhez füződik az astigmia leírása.

Julius Wolff (1836-1902) 1892-ben alkotta meg híres elméletét, miszerint „A csontok alakjában vagy funkciójában bekövetkezô minden változást a belső csontszerkezet megváltozása követ..." Ezt a megállapítást azóta is az oszteológia egyik biomechanikai alaptételének tekintjük.

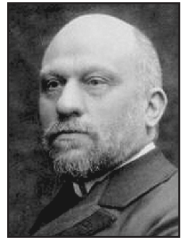

Mosso

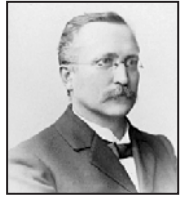

Roux

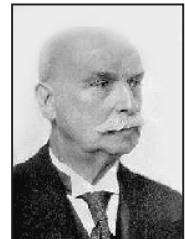

R. A. Fick

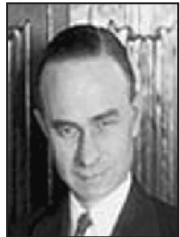

Amar
Angelo Mosso (1848-1910) 1884-ben megalkotta az elsố ergographot, ami számtalan formájával azóta is nélkülözhetetlen eszköze az izmok múködését tanulmányozó kineziológiai vizsgálatoknak.

Wilhelm Roux (1850-1924) nevéhez kötődik a felismerés, hogy az izomhypertophia kialakulásához az izom forszírozott múködése szükséges.

Rudolf A. Fick (1886-1939) állapította meg, hogy az álló testhelyzet nem határozható meg a fekvố testhelyzetből. $\mathrm{Az}$ ágyéki lordosis mértéke állva sokkal nagyob lehet, és a test súlypontja is jelentôsen előretolódik.

Jules Amar (1879-1935) az I. világháború rokkant francia veteránjainak reedukációjával foglalkozott. Munkásságával új korszakot nyitott: a végtagpótló protézisek fejlesztésében az addig pusztán kinematikai meggondolások helyett bevezette az erô- és mozgáselemzést is.

A test mechanikájával foglalkozó átfogó munkát publikált The human motor címen 1914-ben. Egyik legérdekesebb találmánya az ún. állítható fiziológiás mankó, amivel jelentôsen sikerült a hónaljmankó okozta plexus brachialis bénulások számát csökkentenie.

Archibald V. Hill (1886-1977) az izomkontrakció, az idegimpulzusok, az állatok kalorimetriája, az oxigénhiányos izomban felsza-

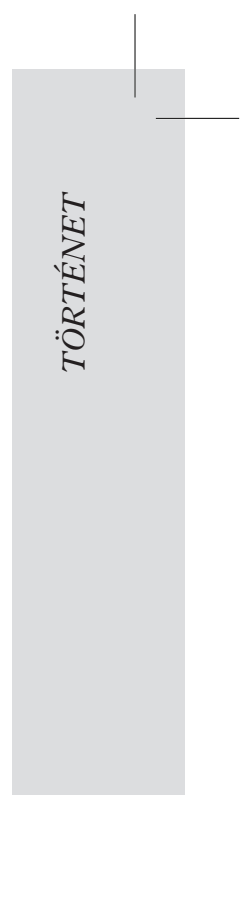




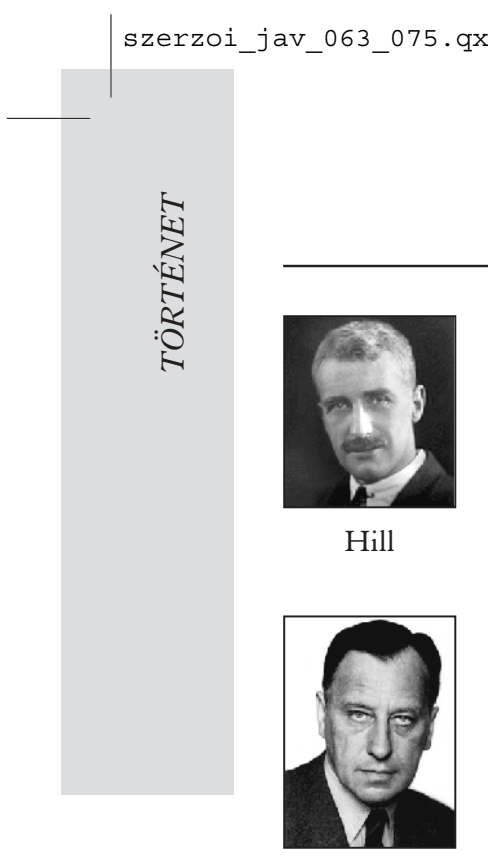

Pauwels porodó tejsav és a hemoglobin kutatásával foglalkozott. Az izmok oxigénfelhasználásával kapcsolatos munkásságát 1922-ben Nobel-díjjal jutalmazták.

Friedrich Pauwels (18851980) a német biomechanika egyik legnagyobb alakja volt. Az ortopédia professzora tiszteletbeli címét is elnyerte pályája végén. Munkájában többek között azt igyekezett bebizonyítani, hogy az izmok és a szalagok olyan gurtniként viselkednek, amelyek a csontokban ébredő feszültséget próbálják csökkenteni.

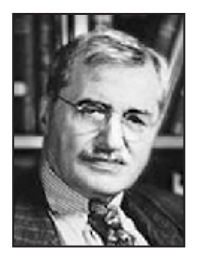

Steindler
Arthur Steindler (1878-1959) Kinesiology of the human body under normal and pathological conditions címú, máig is alapmúnek számító munkájában rendszerezte az addig összegyúlt biomechanikai és kineziológiai alapismereteket, remekül adaptálva azokat a motorizáció és az indusztrializáció okozta megváltozott életkörülményekből adódó speciális helyzetekhez.

A tudományos-technikai forradalom az elmúlt hét évtizedben igen gyors fejlődést eredményezett az élet legtöbb területén. Azt mondhatjuk, hogy az emberiség összes tudományos és technikai vívmányainak 50\%-a a tûz használatba vételétôl számítva kb. 1930-ig született meg, a másik fele pedig azóta. A gyógyászat sem maradt a tudományos-technikai forradalom hatásaitól mentes. Negyedszázada ezen a területen is robbanásszerû fejlôdés indult. Az orvostudomány egészének a fejlődése magával vonta az emberi szervezet felépítése és múködése egyre alaposabb meg- ismerésének a szükségességét és a gyógyítás egyre jobb technikai kiszolgálását. Ugyanakkor háborúk zajlottak, járványok pusztítottak (pl. poliomyelitis 1958), egyre többen sérültek békeidőben is a fejlődő motorizáció miatt, és nem utolsósorban megváltozott az embereknek a betegségükhöz, illetve az egészséghez való viszonya is. Azaz: egyre több oldalról támasztottak igényeket a fejlődés iránt.

$\mathrm{Az}$ orvostudományon belül az ortopédia és az ahhoz szervesen kapcsolódó mozgásszervi traumatológia évtizedek óta a legdinamikusabban fejlődő szakmák közé tartoznak. Állati csontok és különböző fémek, majd múanyagok ötletszerû implantációja már több mint egy évszázada megkezdődött. Az 1960as évektôl pedig sorra kerültek kifejlesztésre a szervezet által jól tolerált és a különböző igénybevételeknek leginkább megfelelố anyagok, amelyektôl hol jó szilárdságot, hol alacsony súrlódást, hol nagy elaszticitást, ugyancsak máskor pedig jó ragasztó tulajdonságot várunk el. A sebészi technika az ipar nyújtotta lehetőségekkel párhuzamosan sokat fejlődött. A fentiek mellett azután a verseny- és a szabadidôsport is a biomechanikai módszerekhez fordult, ebből alakult ki a ma már önálló tudományként is kezelhetô sportmozgás-biomechanika, amely azokat a törvényszerûségeket kutatja, amelyek a mechanika oldaláról befolyásolják a sportteljesítményeket.

Napjainkban a biomechanikai alapelvek jól kidolgozott formákban, alapmúnek számító klasszikus könyvekben világosan le vannak fektetve. Az ép mozgásszervek mechanikai összefüggéseinek megismerésén túlmenően az ortopédiai és traumatológiai betegségek, kóros állapotok és azok konzervatív kezelése vagy mûtét utáni rehabilitációja mind szükségessé teszik az elváltozások biomechanikai vonatkozásainak megértését is. Az egyes mozgásszervi betegségek alaposabb megismerése, illetve a mozgásszervi sebészet és azon belül 
szerzoi_jav_063_075.qxd 2008.06.20. 15:56_Page 75

Biomechanica Hungarica I. évfolyam, 1. szám

is az implantátumtechnika fejlődése megkö-

emberek az újabb tudományos-technikai vívveteli, hogy a mozgásszervi prevencióval, gyómányokat egy jól megalapozott elméleti tudás gyítással és rehabilitációval foglalkozó szak-

és szemlélet birtokában, értően fogadják.

\section{Forrás: Internet.}

Csernátony Zoltán

Debreceni Egyetem, Orvos- és Egészségtudományi Centrum, Ortopédiai Klinika 4012 Debrecen, Nagyerdei krt. 98.

Tel.: (+36) 52 415-494 